\title{
Are There Road Blocks to Access Micro-Credit From Selected Microfinance Banks in Delta State, Nigeria? Implications for Small Scale Farmers Sustainability!
}

\author{
Gbigbi, Theophilus Miebi (Corresponding author) \\ Department of Agricultural Economics and Extension Delta State University, Asaba \\ Campus Asaba, Nigeria
}

E-mail: gbigbitheophilusmiebi@yahoo.com

Received: June 6, 2017 Accepted: June 22, 2017 Published: July 28, 2017

doi:10.5296/jfi.v1i1.11613 URL: http://dx.doi.org/10.5296/jfi.v1i1.11613

\begin{abstract}
The study was carried out to investigate the factors that affect small scale farmers to access fund and utilized for greater efficiency in production in Delta State, Nigeria. The logit model was used to analyze the data. A multi-stage random sampling technique was used for the study. Charts were used to analyze the socioeconomic characteristics of the farmers. About 120 farmers were interviewed using pretested questionnaire. The study showed that sex, education, farm size, cash balance, collateral, frequency of transaction and membership of cooperative society were positive and significant at $1 \%, 5 \%$ and $10 \%$ probability levels respectively. The coefficient of age, interest rate, household size and distance were negative and significant at $10 \%$ and $5 \%$ levels. The results of the study call for policies aimed at encouraging microfinance banks to consider the farmers in accessing credit to increase their output, income and productivity in the study area.
\end{abstract}

Keywords: microfinance banks, farmers, micro-credit, access, Delta State, Nigeria

\section{Introduction}

The agricultural sector plays a significant role in Nigeria's economy contributing about $40 \%$ of the Gross Domestic Product (GDP) Oluwafemi, Adedokun, Ogunleye and Oladokun (2015).and employing $65 \%$ of the adult labour force. It is the small scale farmers that plays active role as instrument of industrial intensification and development of the agricultural sector. Agricultural financing is one of the most important mechanisms to develop farmers into meaningful farming in developing countries. Credit is a major catalyst to increase productivity by small scale farmers in the face of limited capital base Ololade and Olagunju (2013). In the intervening time, access to financial services remain a huge challenge to the 
small scale farmers in Nigeria. Hence, successive governments in the past had formulated and implemented agricultural credit policies and programmes and established credit institutions in a bid to make credit accessible to rural farmers. Despite the lofty intent of governments in Nigeria towards making credit available to majority of farmers, greater proportion of farmers still do not have access to formal credit sources. Improving the availability of credit facilities to agricultural production is one of the incentives that have been proposed for stimulating its growth and realization of its potential contribution to the economy. Arinaitwe and Rogers (2015).contended that limited availability of credit services has undermined farming activities due to lack of capital for investment and has prevented farmers from adopting improved farming practices because of their inability to purchase the necessary inputs required for the production. This was supported by Kitui (2015). that without credit smallholder farmers who dominate the rural setting are unable to adopt most productivity technologies and resulting to the use of low return, subsistence-oriented production practices which therefore continue to underpin most livelihood strategies. Since the provision of credit is an important tool, one question that arises is the extent to which credit can be offered to the farmers to facilitate their taking advantage of the developing entrepreneurial activities. Therefore, an economy cannot achieve the highest possible growth rate unless financial obstacles are overcome. The majority of small scale farmers is not regarded as credit worthy by the formal sector financial institutions and is forced to borrow from the money-lenders in the informal credit market and this has continued to be a constraint limiting smallholders' ability to adopt agricultural technologies and increase productivity (Mwangi, 2011).

The attitude of the conventional finance sectors necessitated the establishment of micro-financing by policy makers, practitioners, and international organizations as a tool for poverty reduction. To this end many developing economies have developed and have been providing credit to small scale farmers through microfinance schemes. The experience of several Asian, African as well as Latin America countries could be a typical example for this Agbaeze and Onwuka (2014)

The emergence of Microfinance in Nigeria was as a result of the increasing poverty levels of the people especially farmers and small scale entrepreneurs (Ademu, 2012). Microfinance can be defined as provision of credit, saving sources and other financial services to low income smallholder farmers to expand their economic activities to improve their living standard. MFIs provide credit to smallholder farmers who do not have access to formal bank credit. The microfinance banks provide micro credit to the farmers to help them engage in new productive agricultural activities and or to expand existing ones. MFBs engage in both individual lending and group lending in providing loans. Andrew, Jan and Adrian (2012) stated that MFBs are specialized banks established to offer financial services to micro-borrowers and the economically active poor. Unfortunately, the results from these programmes and institutions have often differed from the intended objectives

Sustainability in the context of farmers access to micro-credit is premised within the meaning of sustainability as posited by the World Commission on Environment and Development (1987) as cited by: Badri and Mazigh(2016). "meeting the needs of the present without compromising the ability of the future generation to meet their own needs." A positive 
attitude of microfinance banks towards financing resource smallholder farmers can enhance both ecological and socio-economic concepts of sustainability: It can make small-scale farmers production levels relatively adequate for the present and future generations without reducing the ecosystem potentials. Besides, it can increase or maintain production output to meet the social and economic needs of the actual and future generations.

The need therefore to appraise microfinance banks credit access in Delta State by smallholder farmers become necessary. The specific objectives are: Describe the socio-economic characteristics of small scale farmers in the study area, determine the socio-economic determinants of farmers to access microcredit and identify reasons for micro-credit by small scale farmers.

\section{Methodology}

\subsection{Study Area}

Delta State of Nigeria is the study area. It was created in 1991 from old Bendel State. It is made up of 25 local government areas. The State lies between latitude $5^{0} 00$ ' and $6^{0}$ $30^{\prime}$ North and longitudes $5^{\circ} 00^{\prime}$ and $6^{0} 45^{\prime}$ E. Bayelsa, Anambra, Edo and Bight of Benin bound the State on the southeast, northeast, north, northwest and south respectively. It has a land area of 17,698 sq.km with a population of 4.3 million (Federal Republic of Nigeria official Gazette, 2007). The major occupations of these communities is farming and fishing.

\subsection{Sampling Technique/Collection Procedure}

Multi-stage random sampling method was used in the selection of communities/microfinance banks and farmers for the study. In stage one, one local government area was randomly drawn from each of the three agricultural zones (Delta north, Delta south and Delta central) in the State to get a total of three LGAs involved in the survey. Secondly, a total of six microfinance banks were randomly selected. The list of the microfinance services beneficiaries and non-beneficiaries from the list of those that applied but could not get the loan was obtained from the microfinance banks selected. Finally, twenty clients of the institutions (10 beneficiaries and 10 non-beneficiaries) were randomly selected from each of the six microfinance banks. This gives a total sampling size of 120 respondents. This study used primary data. The primary data were collected through structured questionnaire.

\subsection{Analytical Framework}

Financial analyst employ different tools in making rational decisions that will help them achieve the objectives of their firms, but the analytical tool employed varies with the nature of the study. For the purpose of this study, charts and binary logit model were used.

\subsubsection{Logit Model Specification}

The dependent variable is a dummy, which takes a value of zero or one depending on whether or not small scale farmers access microfinance loan. However, the independent variables were both continuous and discrete. The use of qualitative response models in explaining discrete decision making is well documented (Aruk, Paulo, \& Wolfgang, 2014). The simplest 


\section{Macrothink}

of these models, the linear probability model (LPM) is amenable to the OLS method. However, it suffers the limitations that its disturbance term is potentially heteroscedastic and the model's probability predictions are not necessarily bounded within $(0,1)$ (Diebold, 2007). Two transformations of the LPM which bounds probability values within $(0,1)$ are the logit and probit models. There is no clear theoretical or empirical preference between logit and probit models. Both of them transform LPM monotonically to preserve the direction of influence of the regressors or factors on the decision variable. The two models are based on cumulative probability functional transformations; with the probit assuming normality while the logit assumes logistic functional form (Gujarati, 2006). The empirical model is specified thus:

$$
\mathrm{L}_{\mathrm{i}}=\operatorname{In}\left(\mathrm{P}_{\mathrm{i}} /\left|1-\mathrm{P}_{\mathrm{i}}\right|\right)=\alpha+\beta_{\mathrm{i}} \mathrm{X}_{\mathrm{i}}+\varepsilon
$$

Where

$\mathrm{L}_{\mathrm{i}}=\log$ of odds

$P_{i}=$ probability that the $i^{\text {th }}$ farmer is a beneficiary

$1-\mathrm{P}_{\mathrm{i}}=$ probability that the $\mathrm{i}^{\text {th }}$ farmer is non-beneficiary

$\mathrm{X}_{\mathrm{i}}=$ explanatory variables

$\alpha$ and $\beta_{\mathrm{i}}=$ parameters to be estimated

$\varepsilon=$ disturbance term assumed to have zero mean and constant variance

Where specifically,

$$
\begin{gathered}
\mathrm{L}_{1}=\alpha+\beta_{1} \mathrm{X}_{1}+\beta_{2} \mathrm{X}_{2}+\beta_{3} \mathrm{X}_{3}+\beta_{4} \mathrm{X}_{4}+\beta_{5} \mathrm{X}_{5}+\beta_{6} \mathrm{X}_{6}+\beta_{7} \mathrm{X}_{7}+\beta_{8} \mathrm{X}_{8}+\beta_{9} \mathrm{X}_{9}+\beta_{10} \mathrm{X}_{10}+\beta_{11} \mathrm{X}_{11} \\
+\beta_{12} \mathrm{X}_{12}
\end{gathered}
$$

Thus

$\mathrm{L} 1=1$ if beneficiary, otherwise 0

$\mathrm{X}_{1}=\operatorname{sex}$

$\mathrm{X}_{2}=$ age of respondents

$\mathrm{X}_{3}=$ marital status

$\mathrm{X}_{4}=$ household size

$\mathrm{X}_{5}=$ educational level

$\mathrm{X}_{6}=$ farm size $(\mathrm{Ha})$

$\mathrm{X}_{7}=$ cash balance $(\mathrm{N})$

$\mathrm{X}_{8}=$ interest rate

$\mathrm{X}_{9}=$ collateral 


\section{Macrothink}

$\mathrm{X}_{10}=$ frequency of transaction per annum

$\mathrm{X}_{11}=$ membership of cooperative (dummy, member $=1$, otherwise $\left.=0\right)$

$\mathrm{X}_{12}=$ distance from lending institutions $(\mathrm{km})$

\section{Results and Discussion}

Estimation of the descriptive statistics of socio-economic characteristics of the farmers are explained.

\subsection{Age of the Respondents}

The frequency distribution of respondents according to age is shown in Figure 1. The age distribution of respondents showed that majority of the farmers fall between 36 and 55 years of age. This age group accounted for about $52 \%$ of total respondents. This was followed by the age group of between 56 and 65 years, which is $23 \%$ of the total respondents. The least in the structure of age distribution is the age group of less than 25 years. This group accounted for about $3 \%$ of the total respondents. The study generally showed that a greater percentage of respondents $(72 \%)$ are still within the productive age of 20 to 55 years.

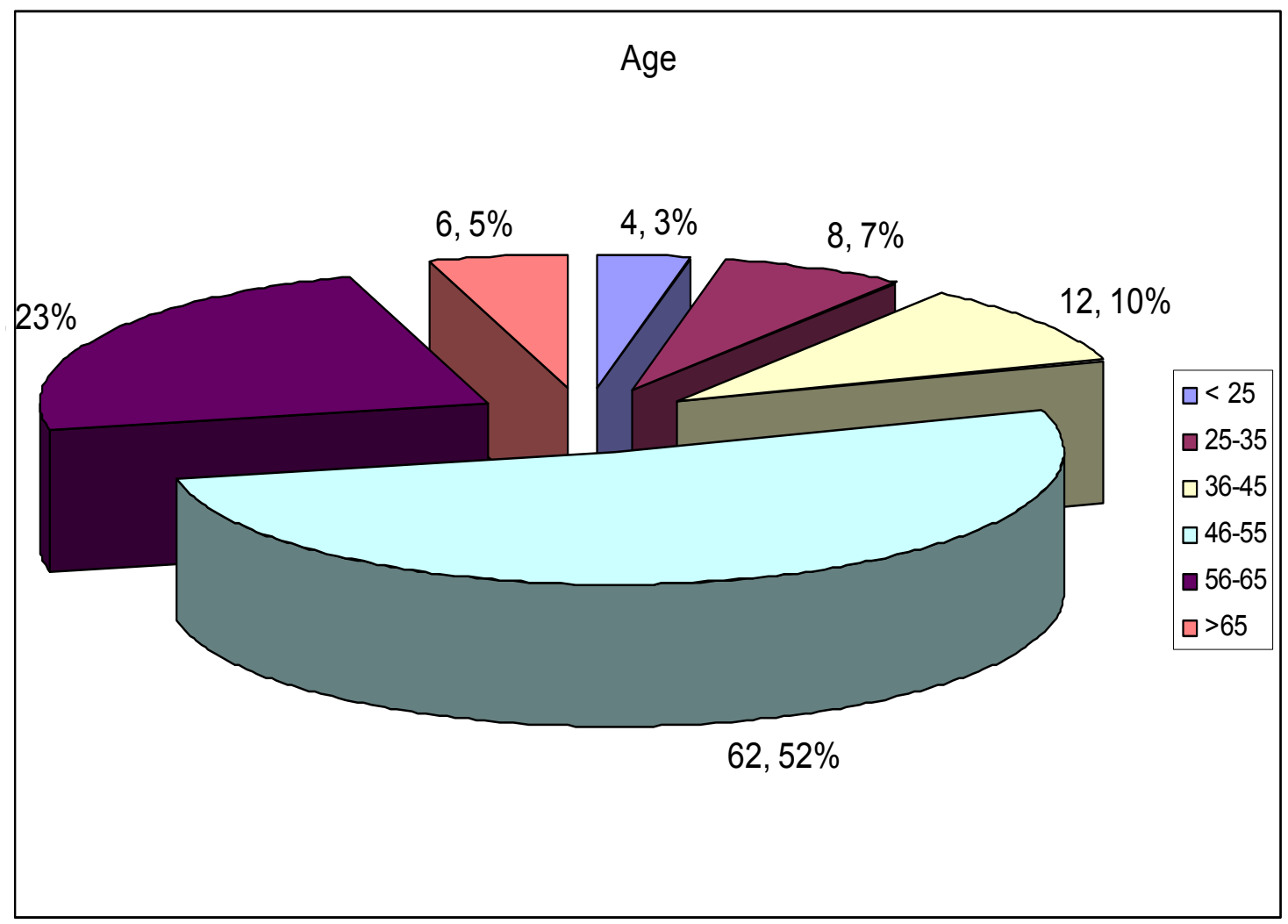

Source: Field survey, 2016

Figure 1. 


\section{Macrothink}

\subsection{Household Size of Respondents}

The frequency distribution of respondents according to family size is shown in Figure 2. About $2 \%$ of the respondents had family size of less than four, while $82 \%$ had family size ranging between four and nine. The remaining $16 \%$ of the respondents had family size of more than nine. The average family size among the respondents was found to be approximately seven.

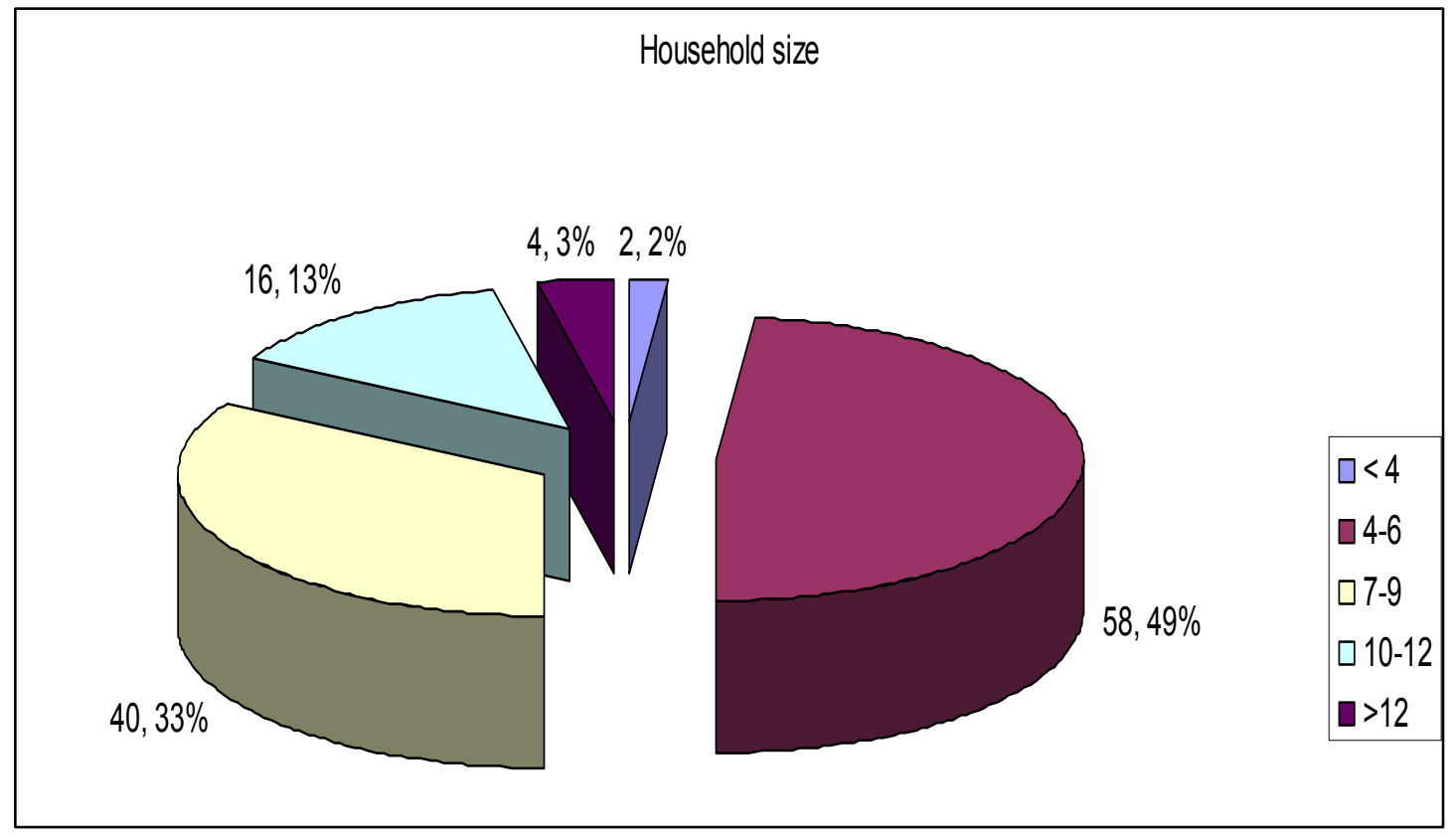

Source: Field survey, 2016

Figure 2. 


\section{Macrothink}

\subsection{Marital Status of Respondents}

It is shown in Figure 3 that $85 \%$ of the respondents were married, while the remaining $15 \%$ were single, divorced or widowed. Marriage is generally associated with increase in family size. Therefore, the credits required by married respondents are expected to be higher than that required by unmarried respondents. Banks also prefer married farmers than unmarried believing that they are more responsible and reliable.

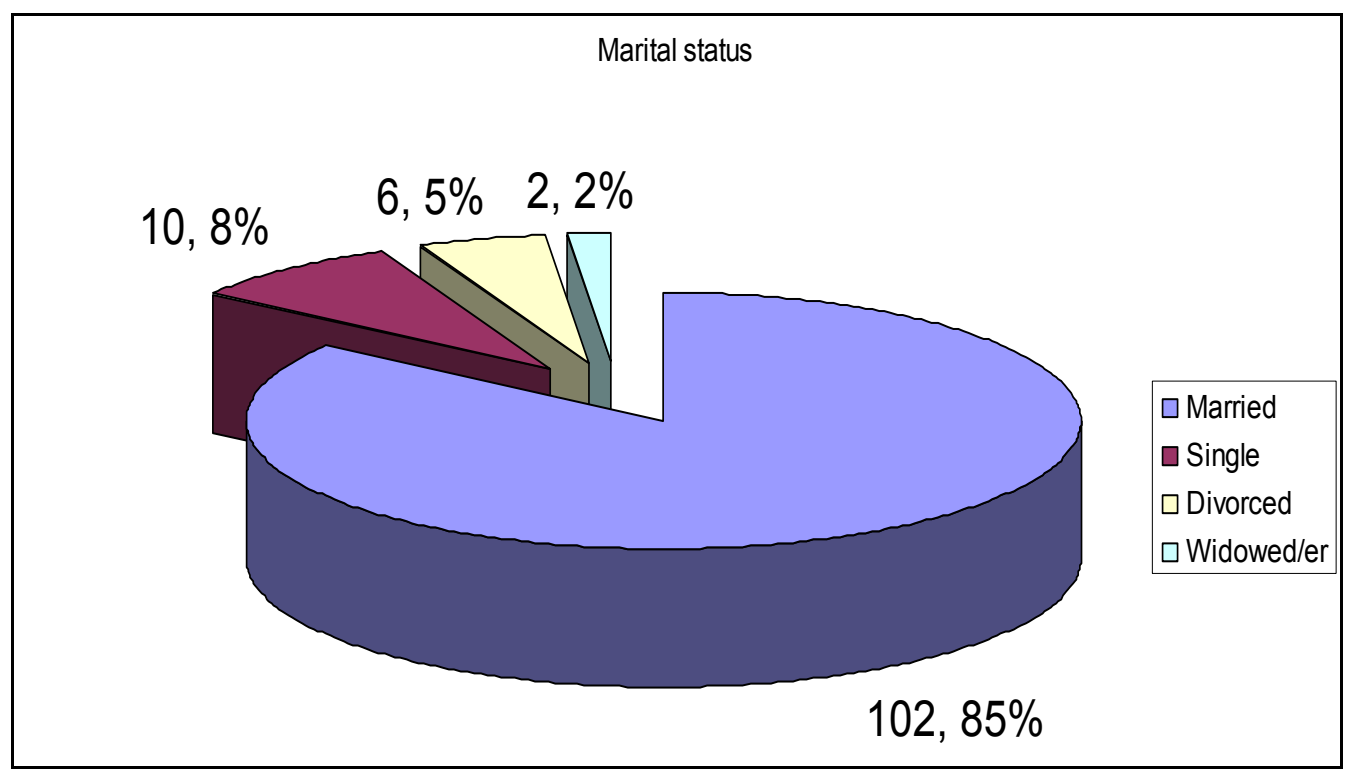

Source: Field survey, 2016

Figure 3 . 
3.4 Farming Experience of the Respondents

Experience in farming could enhance accessibility to micro-credit and efficiency in the management of farm resources, which has direct positive effects on food production. The distribution of respondents according to the number of years spent in farming is presented in Figure 4 . The result shows that $49 \%$ of the farmers spent above 19 years followed by $27 \%$ of the respondents that spent between 15 and 19 years in farming. It implied that the farmers have acquired enough knowledge in farming.

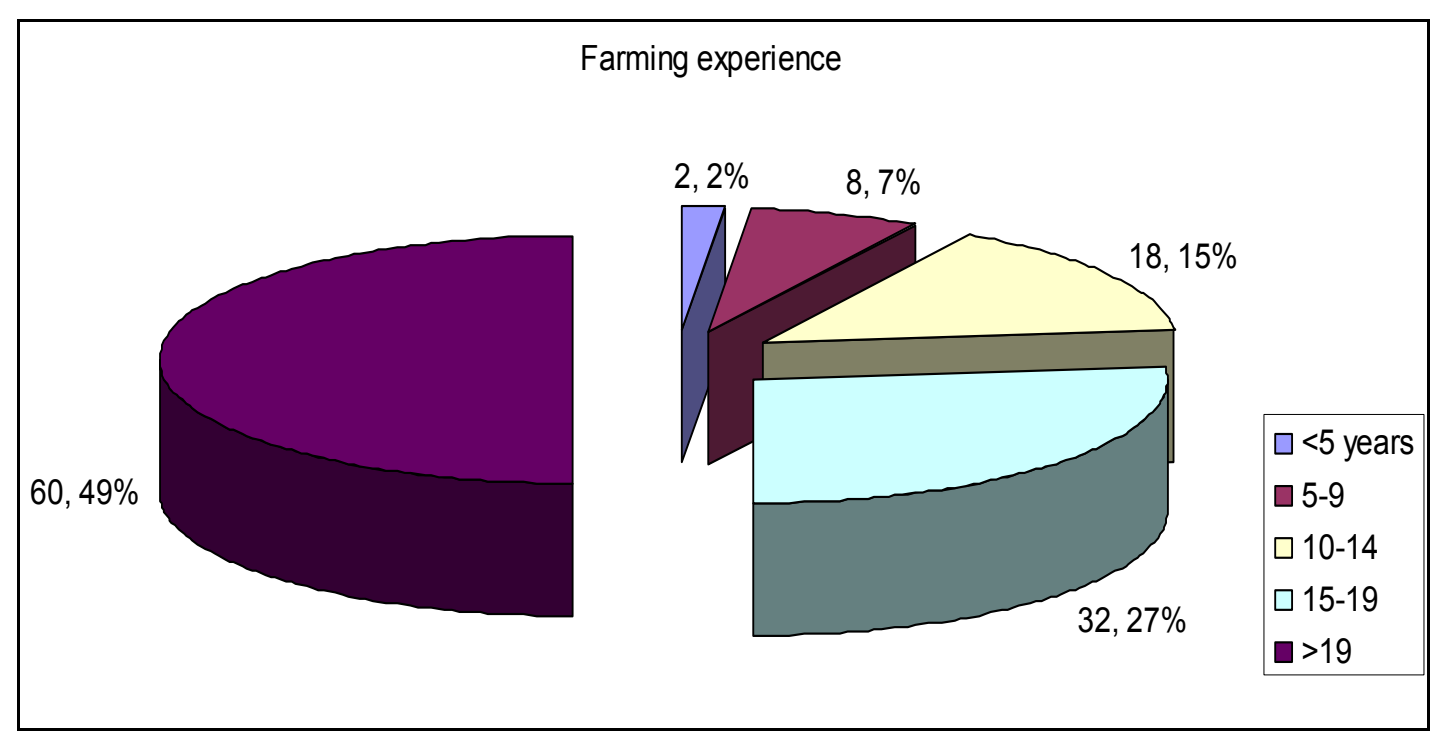

Source: Field survey, 2016

Figure 4. 


\section{Macrothink

\subsection{Educational Status of Respondents}

The level of education of the farmers as can be seen in Figure 5 is generally low. The result shows that $72 \%$ of the farmers interviewed had no formal education. On the other hand, a total of $18 \%$ completed primary school and the remaining $10 \%$ had at least secondary and tertiary school education. Education has great effect on the choice of credit institutions (formal or informal) as well as volume of credit required.

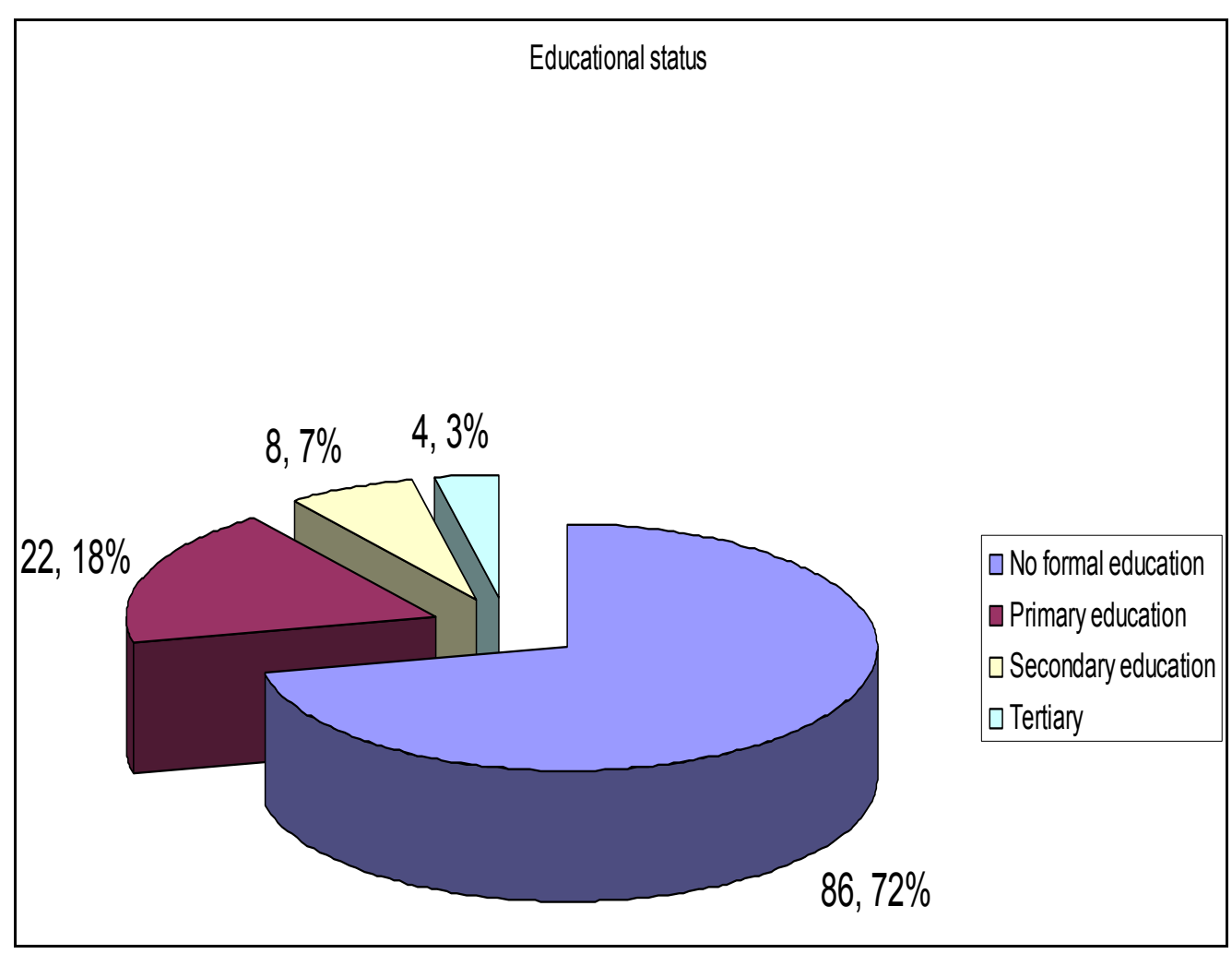

Source: Field survey, 2016

Figure 5. 


\section{Macrothink}

\subsection{Farm-Size}

The result in Figure 6 shows that most farmers in the study area are small scale farmers as $82 \%$ reported farm size of less than a hectare, about $15 \%$ cultivated farm size of 1.0 to 3.0 hectares while only $3 \%$ of the respondents cultivated above 3.0 hectares.

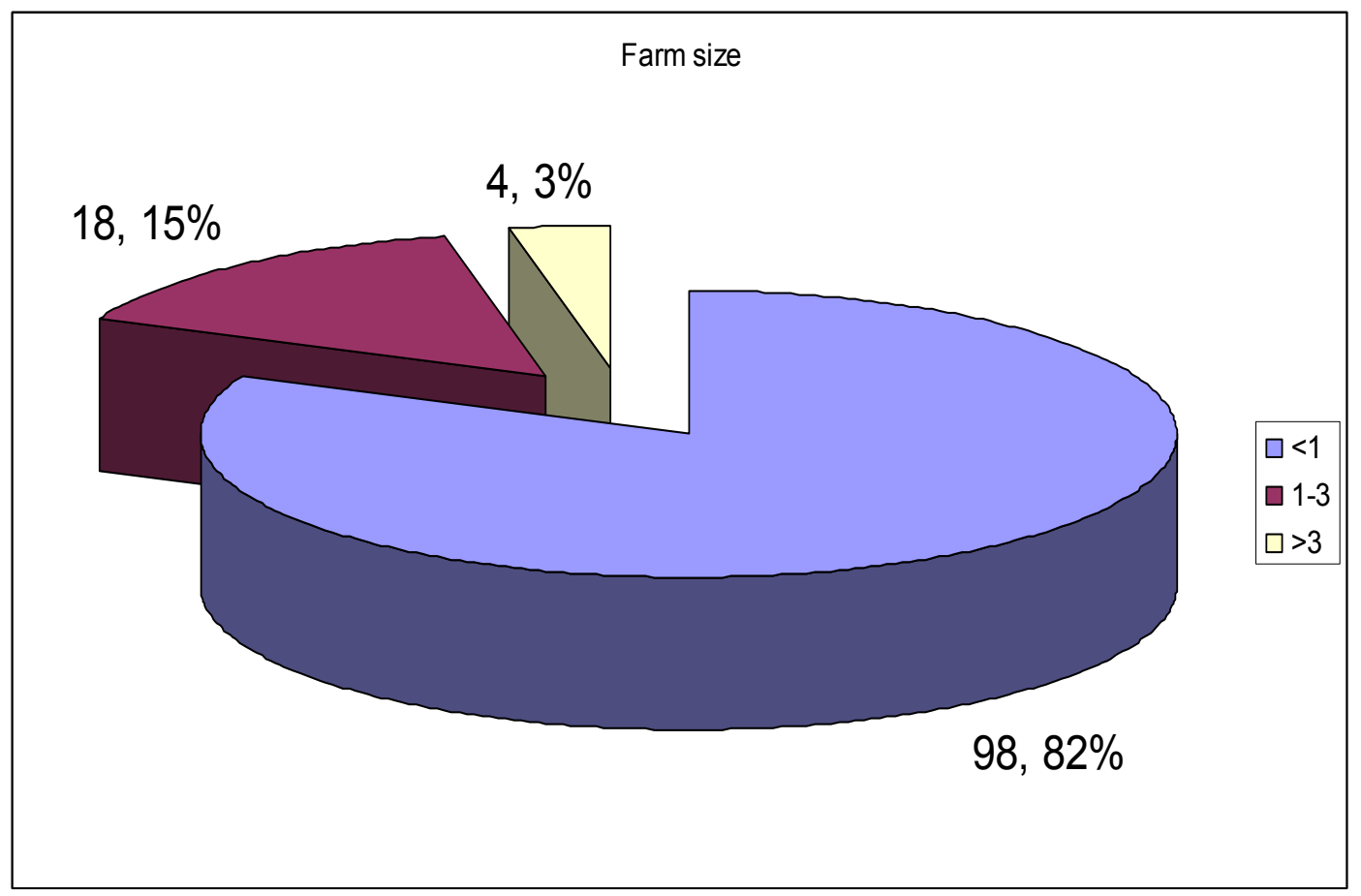

Source: Field survey, 2016

Figure 6. 


\section{Macrothink}

\subsection{Income Level of the Respondents}

The result in Figure 7 showed that the highest proportion $(60.0 \%)$ of the small scale farmers indicated that their annual cash income for the previous year was between N40,001- N80,000 per annum, followed by those (32\%) that earn between N10,000 - N40,000 per annum while the least $(8 \%)$ had annual income of above N80,000 per annum. This implied that small scale farmers $(92.0 \%)$ earn an average of between N10, $000-$ N80, 000 per annum.

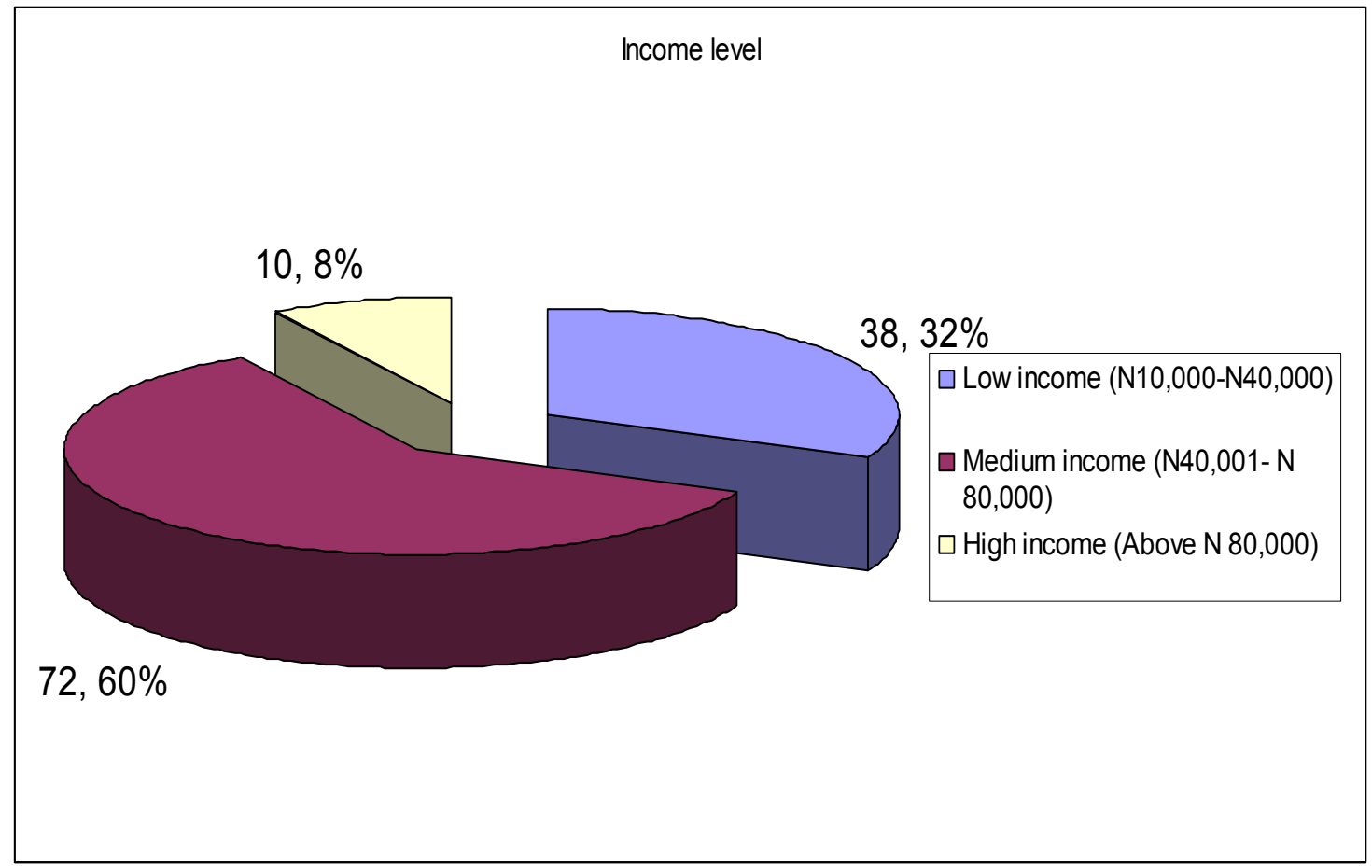

Source: Field survey, 2016

Figure 7. 


\section{Macrothink}

\subsection{Farmers' Reasons for Micro- Credit}

The result in Figure 8 showed that $30 \%$ procure credit to acquire farm assets, $18 \%$ to increase hectares, $14 \%$ to buy seeds/ seedlings, $9 \%$ to buy fertilizer/agrochemicals, $8 \%$ to pay labour, and another $8 \%$ to increase livestock, $7 \%$ to buy more drugs and another $6 \%$ to buy more feeds respectively.

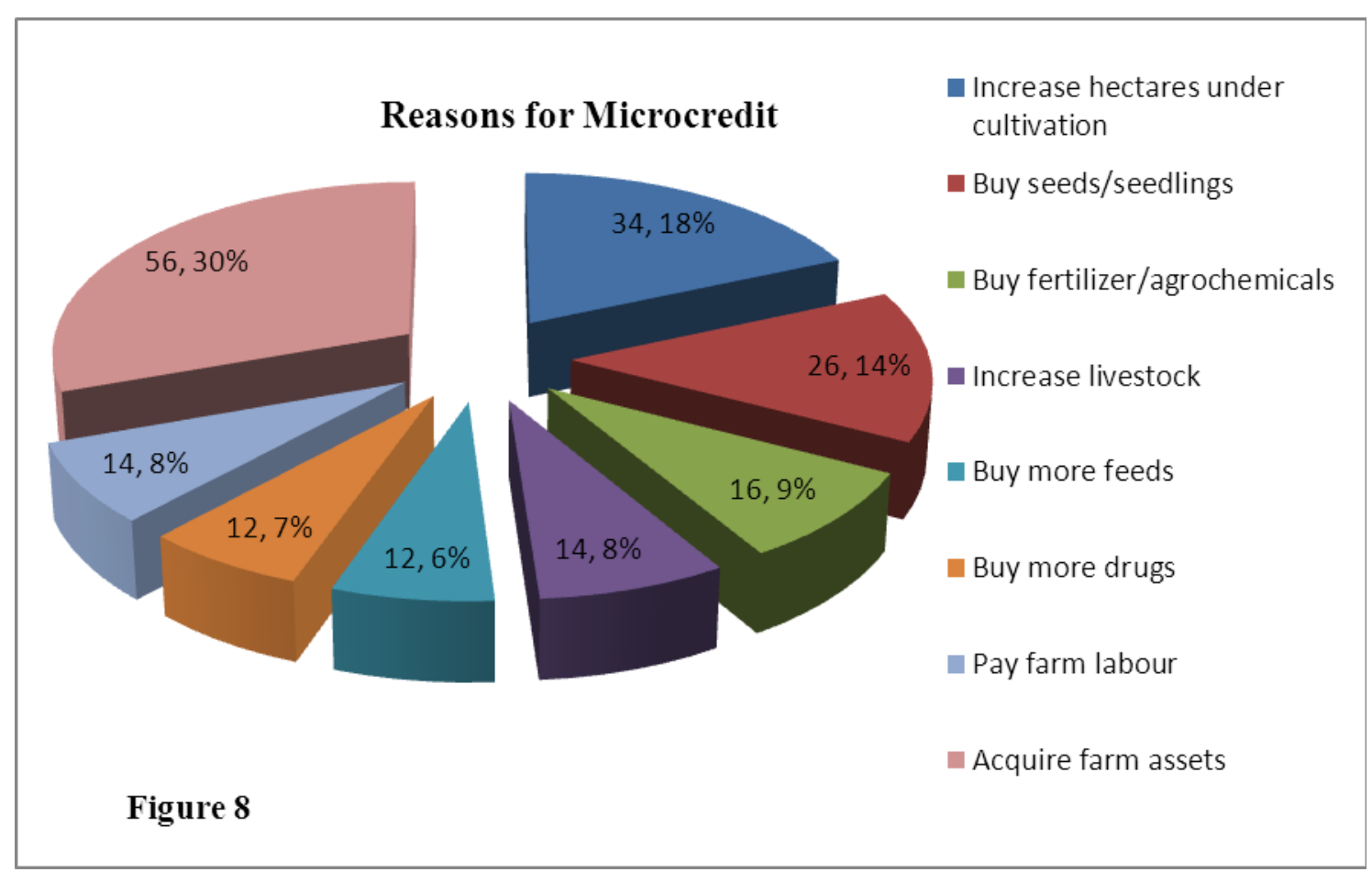

Source: Field survey, 2016

Figure 8. 


\section{Macrothink}

\subsection{Sources of Micro-Credit}

Forty-two (42) percent of the resource poor farmers sourced their finance internally from personal savings, while $22 \%$ sourced funds from loans obtained from co-operative societies. $17 \%$ sourced finance from ministry of agriculture and natural resources, $17 \%$ also sourced from microfinance banks (Figure 9). Lack or collateral securities, however, made it difficult to obtain commercial bank loans as only $2 \%$ could secure it.

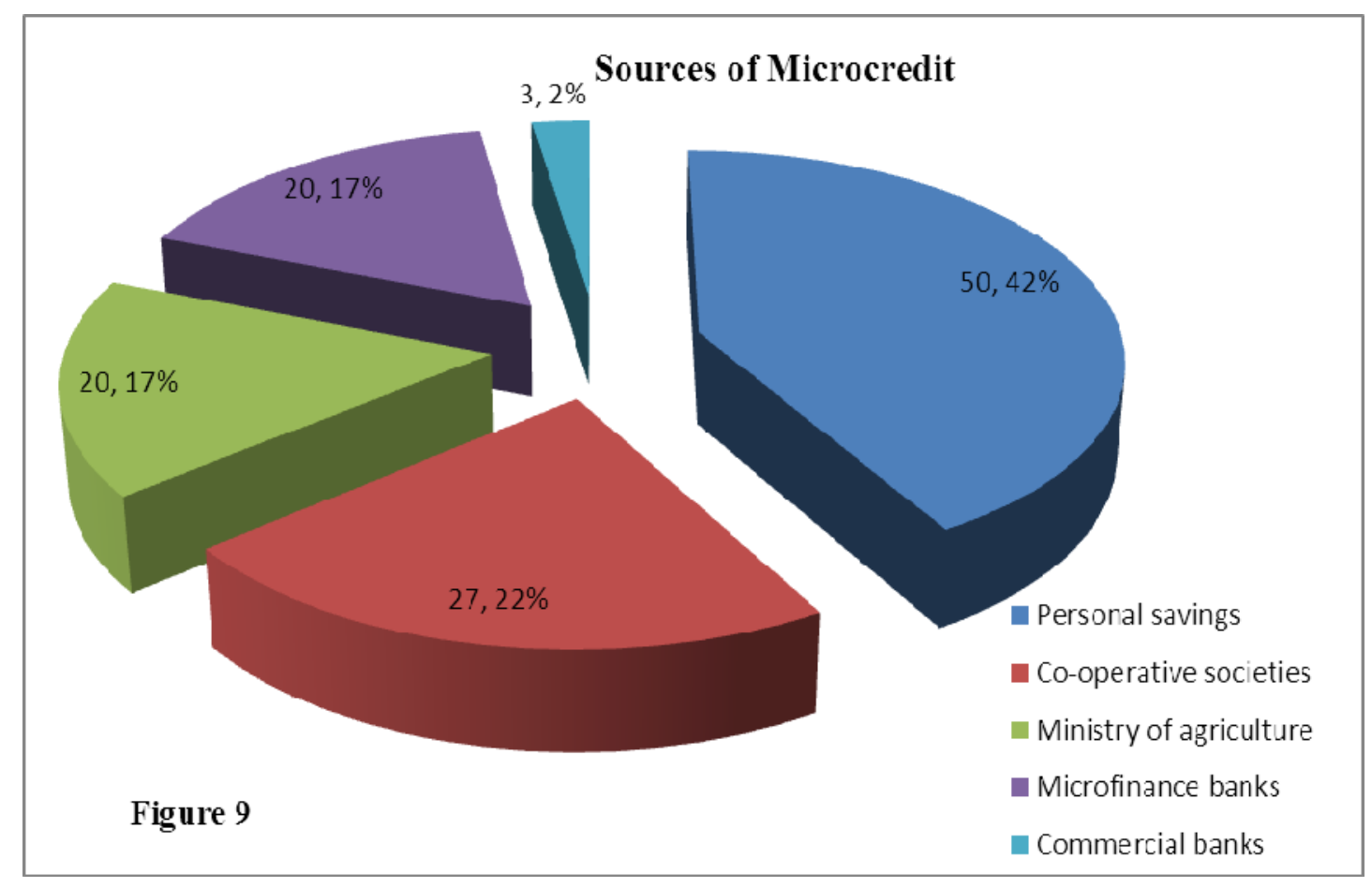

Source: Field survey, 2016

Figure 9.

\section{Determinants of Access to Microcredit by Small Scale Farmers}

The result the logistic regression model is presented in Table 1. It shows that age, interest rate, household size and distance to bank had significant inverse influence on access to credit provided by microfinance banks. The inverse influence of age on access to credit is explained by the fact that older ones could be economically more active and amenable to new ideas, and therefore, more able to understand the cumbersome banking procedure based on experience to securing loans from banks than younger ones. Household size also had significant inverse influence on access to micro-credit. A farmer who has a large household size may divert part of the loan to unintended purposes for the upkeep of their family. Interest rate also had significant negative influence on access to micro-credit. The higher the interest rate charged by the bank, the more the difficulties farmers encountered in accessing the loan. The coefficient of distance was inversely related to access such that one kilometer increase in 


\section{Macrothink}

bank distance will reduce accessibility. This agreed with a priori expectations. Educational level and farm size had significant positive influence on access to micro-credit. Educational level also had positive influence on access to micro-credit. Farmers need to have good education to understand and cope with the lending procedures of the banks to ease accessibility. Farm size may have a positive influence because farmers with larger farms may be consider more credit worthy in term of loan repayment than those with smaller farm sizes. Cash balance and collateral were also found to be positive and significant at $5 \%$ and $1 \%$ probability level. Ability of a farmer to maintain some savings in his/her account shows the credit worthiness which guaranteed express accessibility by the bank. Collateral security also had significant and positive influence on accessibility. Those farmers who had collateral are favoured by the bank than those poor farmers who do not have for fear of loan repayment ability. Frequency of transaction and membership in a cooperative society were found to have significant positive influence on farmers' access to micro-credit by the bank. Frequency of transaction expresses farmers' activeness in their day-to-day economic activities. Most banks prefer to extend their credit facilities to farmers that are economically very active rather than those that are latent. The coefficient for membership of cooperative societies was positively signed and significant at $1 \%$ level of probability. This implies that farmers who belonged to social organizations have easy access than their counterparts who were not members.

Table 1. Factors Affecting Farmers Access to Credit

\begin{tabular}{llll}
\hline Variables & Coefficient & Standard error & Significance level \\
\hline Sex $\left(\mathrm{X}_{1}\right)$ & 1.985 & 0.630 & $0.002 * *$ \\
Age $\left(\mathrm{X}_{2}\right)$ & -0.932 & 0.506 & $0.065 *$ \\
Marital status $\left(\mathrm{X}_{3}\right)$ & 0.030 & 0.576 & 0.416 \\
Household size $\left(\mathrm{X}_{4}\right)$ & -2.186 & 0.112 & $0.006 * *$ \\
Educational level $\left(\mathrm{X}_{5}\right)$ & 0.573 & 0.162 & $0.000 * * *$ \\
Farm size $\left(\mathrm{X}_{6}\right)$ & 0.170 & 0.377 & $0.055 *$ \\
Cash balance $\left(\mathrm{X}_{7}\right)$ & 2.041 & 0.383 & $0.040 * *$ \\
Interest rate $\left(\mathrm{X}_{8}\right)$ & -1.040 & 0.443 & $0.002 * *$ \\
Collateral $\left(\mathrm{X}_{9}\right)$ & 2.354 & 0.342 & $0.000 * * *$ \\
Frequency of transaction $\left(\mathrm{X}_{10}\right)$ & 0.563 & 0.019 & $0.011 * *$ \\
Cooperative $\left(\mathrm{X}_{11}\right)$ & 1.618 & 0.211 & $0.065 * * *$ \\
Distance $\left(\mathrm{X}_{12}\right)$ & -2.771 & 0.503 & $0.027^{* *}$ \\
Constant & 4.281 & 3.024 & $0.012^{* *}$ \\
Chi-square & $2846.618 * *$ & & \\
\hline significant at $10 \% * *=$ significant & $5 \% * * *$ significant at $1 \%$ & \\
\hline
\end{tabular}

Note. $*=$ significant at $10 \%, * *=$ significant at $5 \%, * * *=$ significant at $1 \%$

Source: Field survey, 2016 


\section{Macrothink \\ Journal of Food Industry \\ ISSN 1948-545X \\ 2017, Vol. 1, No. 1}

\section{Conclusion and Recommendations}

The study established that access to credit from microfinance banks has both demand and supply side constraints. These constraints emanate from the farmers themselves and the banks administrative bottlenecks. Therefore, all the factors relative to credit accessibility in this study call for policies aimed at increasing small scale farmers' productivity. Lending procedures should be simplified to ensure easy access of loans to farmers by microfinance banks. MFBs should design more effective follow-up methods, incentives and penalties that would influence borrowers to repay their loans promptly.

\section{References}

Ademu, W. A. (2012). Finance for the Poor: An assessment of the performance of microfinance institutions in Nigeria. African Research Review, 6(2), 312-325. http://dx.doi.org/10.4314/afrrev.v6i2.28.

Agbaeze E. K., \& Onwuka, I. O. (2014). Impact of micro credit on poverty alleviation in Nigeria. The case of Enugu east local council. International Journal of Business and Management Review, 2(1), 27-51.

Andrew, B., Jan, B., \& Adrian, M. (2012). Is sustainable development sustainable? Journal of Integrative Environmental Science, 9(1), 1-8.

Arinaitwe, A., \& Rogers. M. (2015).Improving credit accessibility among SME 's in Uganda. Global Journal of Commerce and Management Perspective, 4(6), 22-30.

Aruk, G., Paulo, N., \& Wolfgang, P. (2014). Random choice as behavioral optimization. Econometrica, 82(5), 1873-1912. http://www.econometricsociety.org/.

Badri, H., \& Mazigh, J. L. (2016). Interaction between financial development and sustainable development, evidence from developing countries: A panel data study. International Journal of Economics and Finance, 8(2), 244-255. http://dx.doi.org/10.5539/ijef.v8n2p243.

Diebold, X. F. (2007). Elements of forecasting ( $4^{\text {th }}$. Ed.). Thomson higher education 5191 Natorp Boulevard Mason, OH 45040 USA.

Federal Republic of Nigeria Official Gazette (2007). Government notice, 24, vol (94), Lagos.

Gujarati, D. N. (2006). Essential of econometrics. McGraw-Hill book company.

Kitui, J. K. (2015).Factors affecting lending by agricultural based financial institutions: A case study of agricultural finance corporation. The International Journal of Business and Management, 3(5),141-169.

Mwangi, M. G. (2011). The effect of micro finance institutions services on the financial performance of micro and small enterprises in India division. A research project report submitted in partial fulfillment of the requirement of master of business administration (MBA) degree, school of business University of Nairobi.

Ololade, R. A., \& Olagunju, F. I. (2013). Determinants of access to credit among rural 


\section{Macrothink}

farmers in Oyo State, Nigeria. Global Journal of Science Frontier Research Agriculture and Veterinary Sciences, 13(2), 16-22.

Oluwafemi, Z. O., Adedokun, M. A.,Ogunleye, A.A \& Oladokun, Y.O.M. (2015).An empirical analysis of the contribution of agricultural sector to Nigerian gross domestic product: Implications for economic development. Developing Country Studies, 5(21), 36-42.

\section{Copyright Disclaimer}

Copyright for this article is retained by the author(s), with first publication rights granted to the journal.

This is an open-access article distributed under the terms and conditions of the Creative Commons Attribution license (http://creativecommons.org/licenses/by/3.0/). 